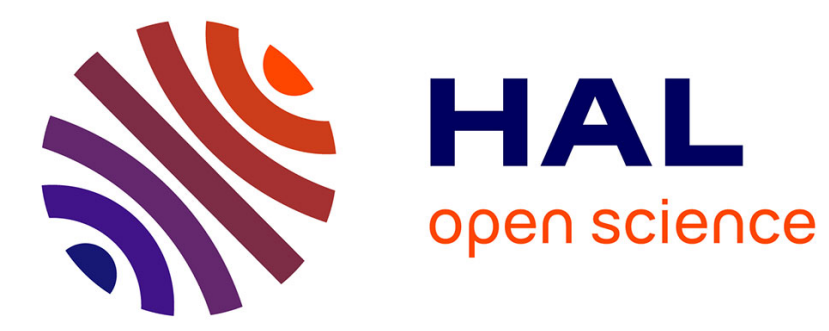

\title{
Is the principle of equal access for all applied in practice to palliative care for the elderly?
}

\author{
Pascale Vassal, Pierre Le Coz, Christian Hervé, Yves Matillon, François
}

Chapuis

\section{- To cite this version:}

Pascale Vassal, Pierre Le Coz, Christian Hervé, Yves Matillon, François Chapuis. Is the principle of equal access for all applied in practice to palliative care for the elderly?. Journal of Palliative Medicine, 2009, 12 (12), pp.1089. 10.1089/jpm.2009.0224 . inserm-00561220

\section{HAL Id: inserm-00561220 https://www.hal.inserm.fr/inserm-00561220}

Submitted on 31 Jan 2011

HAL is a multi-disciplinary open access archive for the deposit and dissemination of scientific research documents, whether they are published or not. The documents may come from teaching and research institutions in France or abroad, or from public or private research centers.
L'archive ouverte pluridisciplinaire HAL, est destinée au dépôt et à la diffusion de documents scientifiques de niveau recherche, publiés ou non, émanant des établissements d'enseignement et de recherche français ou étrangers, des laboratoires publics ou privés. 


\section{Is the Principle of Equal Access for All Applied in Practice to Palliative Care for the Elderly?}

Dear Editor:

A GROWING NUMBER OF ELDERLY people living in nursing homes die without benefiting from the advantages of palliative care. Although many studies have revealed this failure in care, no explanation has yet been found. ${ }^{1,2}$ The aim of this study was to highlight factors explaining the difference in quality of management for the elderly at the end of life.

We carried out an epidemiologic observational study among all nursing homes in the Loire administrative area of France, on a "given day" using two questionnaires, i.e., assessment of patient management (social-demographic, physical, mental, social, and spiritual data) and description of the palliative care facilities (six aspects of palliative care). A logistic model was built to identify explanatory factors able to predict good patient management.

Ninety-two $(88.5 \%)$ nursing homes responded. One hundred eight people, $1.3 \%$ elderly people living in nursing homes, with a mean age of 87.7 years, were considered by the caregivers as requiring palliative care. There are considerable differences, in ease of access to palliative care, for elderly people residing in nursing homes.

Three factors were significantly associated with access to palliative care: (1) Mini Mental State Examination (MMSE): the fewer cognitive problems the end-of-life patients had, the better the overall management was $(p=0,001)$; (2) human caregivers resources (physiotherapists, psychologists, dieticians, voluntary workers): the more available inside nursing homes, the better the overall management of the patients $(p=0.001)$; and (3) urban area management was better, compared to rural area $(p=0.004)$.

The number and variety of human resource people intervening alongside the caregiver reference experts explain the qualitative differences in management of the elderly. Consequently it is necessary to recognize the skills of others in order to involve them and prepare work in collaboration. This leads to the idea that in order to improve the quality of care at the end of life, an increase in the number of these resource people in the nursing homes, or at the very least recognition of their role, should be a priority. As mentioned by Rosenwax et al. ${ }^{3}$ in Australia, our study reveals that the elderly residing in nursing homes in rural areas are disadvantaged with respect to access to palliative care. In our study, which also confirms the conclusions of Chang et al., ${ }^{4}$ our findings show that declining cognitive deficiency correlates to decreased management of symptoms.

Caregivers had significant difficulty identifying patients needing palliative care, since $62 \%$ of the patients in our study suffered from moderate to severe senile dementia. This situation, quite common in the nursing home patient population, further complicates the assessment of pain and other symptoms.

In the aim of improving the quality of care and faced with the malfunctions and failings, palliative care in geriatrics must be developed based on suitable means.

\author{
Pascale Vassal, M.D. ${ }^{1}$ \\ Pierre Le Coz, M.P.H ${ }^{2}$ \\ Christian Herve, M.D., Ph.D. ${ }^{3}$ \\ Yves Matillon, M.D., Ph.D. ${ }^{4}$ \\ François Chapuis, M.D., M.P.H., Ph.D. ${ }^{4}$
}

\section{References}

1. Coventry P, Grande G, Richards D, Todd C: Prediction of appropriate timing of palliative care for older adults with non-malignant life-threatening disease: A systematic review. Age Ageing 2005;34:218-227.

2. Zerzan J, Stearms S, Hanson L: Access to palliative care and hospice in nursing homes. JAMA 2000;284:2489-2494.

3. Rosenwax L, Mac Namara B: Who receives specialist palliative care in Western Australia and who misses out? Palliat Med 2006;20:439-445.

4. Chang E, Handock K: Palliative care for end-stage dementia: A discussion of the implications for education of health care professionals. Nurse Educ Today 2005;25:326-332.

Address correspondence to: Pascale Vassal, M.D.

14 Chemin Claude Berthier

Saint Etienne

Loire 42100

France

E-mail: pasvassal@aol.com

\footnotetext{
${ }^{1}$ Loire, France.

${ }^{2}$ Marseille, France.

${ }^{3}$ Paris, France.

${ }^{4}$ Lyon, France.
} 
